Société d'histoire de la révolution de 1848 et des

révolutions du XIXe siècle

$22 \mid 2001$

Autour de Décembre 1851

\title{
La célébration du coup d'État de 1851 : symbolique politique et politique des symboles
}

\section{Rémi Dalisson}

\section{OpenEdition \\ Journals}

Édition électronique

URL : http://journals.openedition.org/rh19/250

DOI : $10.4000 /$ rh 19.250

ISSN : $1777-5329$

\section{Éditeur}

La Société de 1848

\section{Édition imprimée}

Date de publication : 1 juin 2001

Pagination : 77-95

ISSN : 1265-1354

\section{Référence électronique}

Rémi Dalisson, «La célébration du coup d'État de 1851 : symbolique politique et politique des symboles », Revue d'histoire du XIXe siècle [En ligne], 22 | 2001, mis en ligne le 30 novembre 2016, consulté le 01 mai 2019. URL : http://journals.openedition.org/rh19/250 ; DOI : 10.4000/rh19.250

Ce document a été généré automatiquement le 1 mai 2019.

Tous droits réservés 


\title{
La célébration du coup d'État de 1851 : symbolique politique, politique des symboles
}

\author{
Rémi Dalisson
}

\section{ABSTRACTS}

The celebration of the $\mathbf{1 8 5 1}$ 's coup : political symbols and the policy of symbolsif the 1851 coup was a success, it was also because of a meticulous allegorical preparation, a true staging of politics and its symbols. The coup was immediately utilized by the government which, with its the emblematic celebration of January 1852, succeeded in setting it in the French cultural background. This ceremony was to close the journey begun in December 1848 and symbolise the continuity between the new regime and the empire. As early as 1849 , the "Prince-president" took steps to build his coup symbolically through a cultural policy and didactic holidays. Even before December 1851, he then provoked resistances which were just as allegorical. Throughout the country, local authorities were summoned to celebrate January $1^{\text {st }}$ and $11^{\text {th }}$ in order to impose new symbols, widely inspired by imperial past. So a myth and popular images were built. But the December break was so important that reactions grew in number and intensity, especially in this field. With the popular support generated by the Napoleonic legend, the contrasted celebrations of January 1852 conveyed the legitimising importance of the cultural and symbolic construction of the coup. They also illustrated the vitality of "protest sociability" which opened a breach into the conditioning of the masses and the unity of the symbolic authoritarian politics.

Si le coup d'État de 1851 réussit, ce fut aussi grâce à une préparation allégorique méticuleuse, véritable mise en scène de la politique et de ses symboles. Il fut immédiatement instrumentalisé 
par le pouvoir, qui parvint à l'inscrire dans le paysage culturel Français par sa célébration emblématique de janvier 1852. Cette cérémonie devait clore l'aventure entamée en décembre 1848 et symboliser la continuité entre le nouveau régime et l'Empire. Dès 1849, le PrincePrésident entreprit donc de bâtir symboliquement son coup de force, en instrumentalisant sa politique des symboles et fêtes allégoriques. Il provoqua alors, avant même décembre 1851, des résistances tout aussi allégoriques. Partout, les autorités furent sommées, par de nombreux textes, de célébrer les 1er-11 janvier pour imposer de nouveaux symboles, inspirés du passé impérial. Ainsi se bâtit un mythe et des images populaires. Mais la rupture de décembre avait été telle que les réactions se multiplièrent, notamment dans ce domaine allusif. Face à l'adhésion née de la légende napoléonienne, les célébrations de janvier 1852 traduisirent bien l'importance légitimante de la construction culturelle et symbolique du coup d'État. Elles illustrèrent à l'inverse la vitalité d'une "sociabilité protestataire" qui ouvrit une brèche dans le conditionnement des masses et l'unicité des politiques symboliques autoritaires

\section{INDEX}

Mots-clés: Coup d'Etat, Fête, Histoire culturelle, Histoire politique, Politisation, Sociabilité 